\title{
Insekticid fipronil \\ u proizvodima od peradi \\ u Europskoj uniji
}

\author{
Maja Đokić, Marija Sedak i Nina Bilandžic*
}

\section{Sažetak}

Fipronil je insekticid širokog spektra djelovanja koji se ubraja u skupinu fenilpirazola. Prvi je insekticid koji je djelovao ciljajući GABA (gama-aminomaslačnu kiselinu) receptor i imao povoljnu selektivnu toksičnost prema insektima, ali ne i sisavcima. U skladu s uredbom (EZ) br. 1107/2009. fipronil nije odobren u sredstvima za zaštitu bilja te je zabranjeno tretiranje životinja namijenjenih za prehranu ljudi u Europskoj uniji (EU). Najveća dopuštena količina (NDK) fipronila ustvrđena je prema Uredbi 396/2005. o maksimalnim razinama ostataka pesticida u i na hrani i hrani za životinje biljnog i životinjskog podrijetla te za jaja i meso peradi iznosi $0,005 \mathrm{mg} / \mathrm{kg}$. Svjetska zdravstvena organizacija (WHO) klasificirala je fipronil kao umjereno opasan pesticid II klase. Konzumiranje malih količina fipronila izaziva mučninu, glavobolju, povraćanje, bol u želucu, slabost i vrtoglavicu. Nakon apsorpcije $\mathrm{u}$ ljudi distribuira se u tkiva i oslobađa aktivne metabolite koji se nakupljaju uglavnom u masnom tkivu. Eksperimenti na miševima pokazali su da produljena izloženost visokim dozama fipronila prouzroči rak štitnjače u mužjaka i ženki. Pojava fipronila u jajima u EU zabilježena je 2016. godine u Belgiji. Kao posljedica ustvrđene zlouporabe fipronila na farmama pilića, države članice EU i Europska komisija dogovorile su provedbu ad-hoc monitoringa na ostatke insekticida fipronila i drugih akaricida u jajima i mesu peradi. Europska agencija za sigurnost hrane (EFSA) objavila je izvješće o rezultatima monitoringa te su u ukupnoj količini od 5439 uzoraka jaja i mesa peradi u zemljama članicama EU i Islandu u 742 uzorka $(13,6 \%)$ ustvrđene količine veće od zakonski dopuštenih. Većina nesukladnih rezultata odnosila se na fipronil u uzorcima kokošjih jaja i masnog tkiva kokoši nesilica. U uzorcima iz Republike Hrvatske nisu ustvrđeni nesukladni rezultati. Uzorci koji su prekoračili zakonsko ograničenje bili su podrijetlom iz Nizozemske, Italije, Njemačke, Poljske, Mađarske, Francuske, Slovenije i Grčke. Članice EU su u kontroli proizvoda koji se upućuju na tržište EU nesukladne rezultate fipronila prijavljivale u razdoblju 2017.-2019. putem centralnog sustava brzog uzbunjivanja za hranu i hranu za životinje - RASFF. Ukupno je prijavljeno 128 različitih proizvoda $\mathrm{s}$ nesukladnim koncentracijama fipronila, a najviše se obavijesti odnosilo na jaja i proizvode od jaja. Pri tome je u okviru poduzetih mjera za čak 45 prijava provedeno povlačenje kontaminiranih jaja s tržišta, obavljeno je po 9 zapljena i 9 službenih pritvora. Na temelju

Dr. sc. Maja ĐOKIĆ, dipl. ing. kem. teh., dr. sc. Marija SEDAK, dipl. ing. prehr. tehnol., dr. sc. Nina BILANDŽIĆ* , dipl. ing. biotehnol., znanstvena savjetnica (dopisni autor, e-mail: bilandzic@veinst.hr) Hrvatski veterinarski institut, Zagreb, Hrvatska 
ustvrđenih nesukladnih nalaza fipronila Europska komisija je prema Provedbenoj Uredbi Komisije (EU) 2019/533 uvrstila njegovu kontrolu u okviru koordiniranog višegodišnjeg programa kontrole EU za razdoblje 2020.-2022.

Ključne riječi: fipronil, pesticidi, jaja, EFSA, sigurnost hrane

\section{Uvod}

Fipronil je insekticid širokog spektra djelovanja koji spada u skupinu fenilpirazola. Proizveden je 1987. godine te je prvotno razvijen za uporabu $u$ suzbijanju štetočina $u$ poljoprivredi i javnom zdravstvu (Zhang i sur., 2016.). Fipronil je prvi insekticid koji je djelovao ciljajući GABA (gama-aminomaslačnu kiselinu) receptor i imao povoljnu selektivnu toksičnost prema insektima, a ne sisavcima (Hainzl i Casida, 1996., Hainzl i sur., 1998., Ikeda i sur., 2004.).

Prema IUPAC nomenklaturi kemijsko ime fipronila je 5-amino-1-[2,6-dikloro4-(trifluorometil)fenil]-4-[(trifluorometil) sulfinil]-1H-pirazol-3-karbonitril, a njegova molekularna masa je 437,15 g/moL. Molekula fipronila na položaju 4 sadrži trifluormetilnu grupu (CF3) (slika 1) što joj omogućuje veću liposolubilnost te tako olakšava njezino taloženje u masnom tkivu i doprinosi njezinom produljenom učinku u organizmu (Magalhães i sur., 2018.). Osim toga, trifluormetilna grupa (CF3) doprinosi njegovoj izvanrednoj snazi na terenu (Hainzl i Casida, 1996.). Fipronil pokazuje visoku osjetljivost na insekte otporne na ciklopentadienske, organofosforne i organoklorne pesticide te na piretroide i karbamate, a ujedno nema unakrsnu rezistentnost s postojećim pesticidima (Zhang i sur., 2016.).

Topljivost fipronila $u$ vodi iznosi $2,4 \mathrm{mg} / \mathrm{L}$ pri $\mathrm{pH} 5$ te $22 \mathrm{mg} / \mathrm{L}$ pri $\mathrm{pH} 9$ te je u tim uvjetima stabilan 14,5 dana. Gustoća mu je veća od vode i može se razgraditi fotolizom i hidrolizom $u$ alkalnim uvjetima. Fipronil ne hlapi, jer ima relativno nizak tlak para, a u zraku se nalazi samo ako se koristi u obliku spreja. Odlikuje se niskom pokretljivošću u tlu što rezultira niskim potencijalom kontaminacije. Međutim, ima tendenciju raspršivanja što olakšava njegovu razgradnju mikroorganizmima (Magalhães i sur., 2018.).

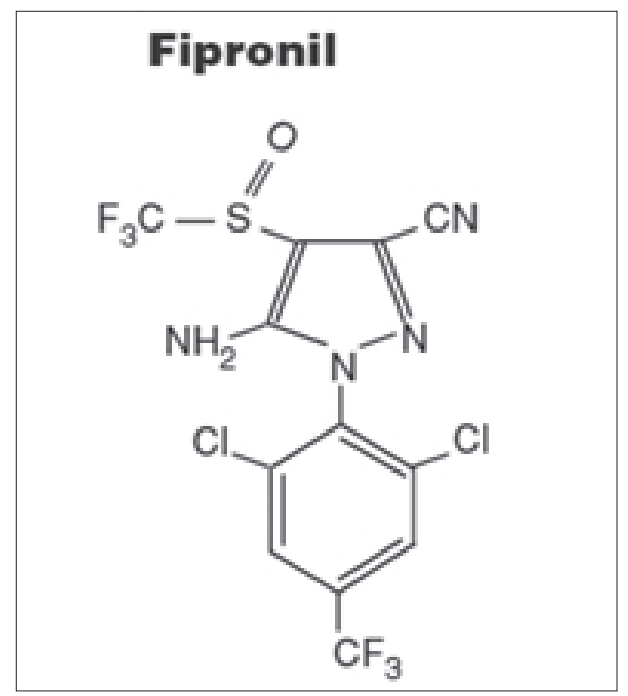

Slika 1. Kemijska struktura fipronila

Svjetska zdravstvena organizacija (WHO) klasificirala je fipronil kao umjereno opasan pesticid II klase (WHO, 2010.). Fipronil pokazuje akutnu toksičnost $\mathrm{u}$ eksperimentalnih životinja kada se unese $u$ organizam oralnim putem, kroz kožu ili udisanjem. Ne izaziva iritacije kože ili sluznice oka, niti izaziva alergiju na koži. U testovima koji su provedeni na miševima, štakorima, psima i zečevima fipronil je djelovao na živčani sustav, ali u odraslih životinja utjecaj je bio reverzibilan. U štakora je 
neurotoksičnost uočena u podmlatka, nakon što je ova supstanca davana ženkama. U štakora i miševa primijećen je i toksični utjecaj na jetru (EFSA, 2006.). Istraživanje koje su proveli Mohamed i sur. (2004.) oralnom primjenom 4 $\mathrm{mg} / \mathrm{kg}$ fipronila $\mathrm{u}$ štakora pokazalo je poluvrijeme eliminacije od približno 8,5 sati, dok je to vrijeme za fipronil-sulfon iznosilo čak 208 sati. Ovo kašnjenje $\mathrm{u}$ polovremenu eliminacije fipronilsulfona može se objasniti njegovom koncentracijom u masnom tkivu i visokim stupnjem jetrene cirkulacije (Mohamed i sur., 2004.). Čak 45-75 \% fipronila u sisavaca eliminira se putem fecesa, a 5-25 $\%$ putem urina (IPCS/INCHEM, 1997.).

U okolišu fipronil brzo degradira procesima redukcije, hidrolize, oksidacije i fotolize pri čemu dolazi do stvaranja pet glavnih aktivnih metabolita: fipronil-sulfida (M\&B 45950)-produkt redukcije $\mathrm{u}$ tlu; fipronil-amida (RPA 200766)- produkt hidrolize $u$ vodi $i \mathrm{tlu}$; fipronil-sulfona (M\&B 46136)-produkt oksidacije u tlu; fipronil-desulfinila (M\&B 46513)-produkt fitolize; fipronilsulfonska kiselina (RPA 104615). Kod sisavaca, glavni metabolit je fipronilsulfon kojeg nalazimo $u$ jetri, masnom tkivu i urinu (Magalhães i sur., 2018.). U ljudi ovaj metabolit (fipronil-sulfon) nastaje pod utjecajem enzima citokorom P450 (Zhao i sur., 2005.). U in vivo studiji Durham i sur. (2002.) otkrili su da fipronil-sufon nastaje posredovanjem enzima monooksigenaza.

\section{Mehanizam djelovanja}

Neurotransmitor gamma aminomaslačna kiselina (GABA) ima važnu ulogu u prijenosu živčanih informacija, a posredno je uključen i u kontrolu brojnih funkcija u organizmu. Fipronil je insekticid koji interferira s kloridnim kanalima vezanim na receptorima GABA djelujući kao nekompetitivni blokator tih kanala. $\mathrm{Na}$ taj način inhi- bira prijenos živčanih impulsa između živčanih stanica (Islam i Lynch, 2012.). Ovakvo GABA antagonistično djelovanje pojačava živčane impulse te vodi do pretjerane neuronske aktivnosti i smrti insekta hiperekscitacijom, s obzirom na činjenicu da je GABA glavni inhibicijski neurotransmiter živčanog sustava (Ohi i sur., 2004.).

GABA djeluje na tri različite vrste receptora: GABAA receptori (koji u svom sastavu imaju ionski kanal), GABAB receptori (vezani na G-proteine) i GABAC receptori (koji se novom nomenkalturom svrstavaju u porodicu GABAA receptora; a još se nazivaju o receptori) (Olsen i Sieghart, 2008.). GABAA receptori su ionotropni transmembranski glikoproteini, sastavljeni od polipeptidnih podjedinica koje okružuju centralni anionski kanalić. Protokom iona klora kroz tako formirani kanalić regulira se podražljivost neurona (Bauman i sur., 2002.). GABAA receptori uglavnom su oblikovani od pet podjedinica, a do danas je izolirano sedam porodica podjedinica iz živčanog sustava sisavaca, a to su: $\alpha, \beta, \gamma, \delta, \varepsilon, \pi$, @ i $\Theta$ (Olsen i Sieghart, 2008.). Najmanje jedna $\alpha$, jedna $\beta$ i jedna $\gamma$ podjedinica potrebne su za cjelovito funkcioniranje receptora. Poznato je da se in vitro fipronil spaja na homogeomerni receptor $\beta 3$ relativno slabo, a na nativni receptor insekata visokim afinitetom, približno 100 puta jačim u usporedbi s receptorima sisavaca (Mohamed i sur., 2004.).

Fipronil ima snažan afinitet prema GABAergičkim receptorima beskralježnjaka, što ga čini toksičnijim za insekte nego za sisavce zbog toga što je živčani sustav insekata mnogo jednostavniji od živčanog sustava sisavaca, a i GABAergički receptori insekata i sisavaca su strukturno različiti (Narahashi i sur., 2007.). Također, insekti imaju glutamatergični sustav koji je povezan i s kloridnim kanalima, što ga čini kritičnom metom fipronila (Zhao i sur., 2005., Narahashi i sur., 2007.). 


\section{Toksičnost fipronila}

Fipronil utječe i na reproduktivni sustav i razvoj ploda. Studije na miševima pokazale su da fipronil smanjuje količine legla i tjelesnu težinu životinja, reducira postotak parenja i smanjuje plodnost (Terçariol, 2007.). Vjeruje se da su ove promjene povezane s utjecajem fipronila na štitnjaču, jetru i hipofizu (Tingle i sur., 2003.). Ohi i sur. (2004.) pokazali su da su štetni učinci fipronila na reproduktivni trakt miševa povezani s promjenama $u$ endokrinom sustavu, posebno u razinama progesterona i estradiola tijekom spolnog ciklusa (druga faza ciklusa) i perioda gestacije miševa.

Najvažniji put unosa fipronila u ljude je putem kože, očiju ili slučajnom ingestijom. Kontakt izravan i kratak može izazvati iritaciju na koži i očima. Pri gutanju malih količina tvari javlja se osjećaj mučnine, glavobolje, povraćanje, bol u želucu, slabost i vrtoglavica. Takvi su simptomi prolazni, jer se ubrzo nakon apsorpcije fipronil eliminira putem fecesa i mokraće (NPIC, 2009., NCAMP, 2016.). Međutim, jednom kad ga tijelo apsorbira, ta se supstanca distribuira u tkivima i oslobađa aktivne metabolite koji se nakupljaju uglavnom u masnom tkivu (NCAMP, 2016.). Literatura dalje navodi da je fipronil kancerogen. U mužjaka i ženki miševa produljena izloženost visokim dozama fipronila može prouzročiti rak štitnjače. Međutim, do danas nema dokaza o kancerogenom učinku kod ljudi (NCAP, 2005., NPIC, 2009., NCAMP, 2016.). Szegedi i sur. (2005.) ustvrdili su da su glavni uzroci trovanja ljudi fipronilom slučajni i profesionalni, što rezultira umjerenim i privremenim učincima. Djeca su mnogo osjetljivija na toksične učinke bilo kojeg pesticida. Čak i ako ne pokazuju bilo kakve kliničke simptome mogu pokazati loše rezultate na neurobihevioralnim testovima. S obzirom na tu činjenicu, uporaba neurobihevioralnih testova pre- poručuje se za procjenu neurotoksičnosti kemijskih sredstava poput fipronila (Terçariol, 2007.).

\section{Pojava povišenih koncentracija fipronila u EU}

U skladu s uredbom(EZ) br. 1107/2009. fipronil nije odobren $\mathrm{u}$ sredstvima $\mathrm{za}$ zaštitu bilja (EC, 2009.). U Europskoj uniji (EU) je zabranjeno tretiranje fipronilom životinja namijenjenih za prehranu ljudi (EFSA, 2018.). Kao veterinarsko medicinski proizvod (VMP), prema Upravi za veterinarstvo i sigurnost hrane, u Hrvatskoj je dopušten kao antiparazitik $\mathrm{u}$ pasa i mačaka (Ministarstvo poljoprivrede, 2020.). Najveća dopuštena količina (NDK) fipronila ustvrđena je Uredbom Europskog parlamenta i Vijeća (EZ) br. 396/2005. o maksimalnim razinama ostataka pesticida u i na hrani i hrani za životinje biljnog i životinjskog podrijetla te ona za kokošja jaja i meso peradi iznosi $0,005 \mathrm{mg} / \mathrm{kg}$ što je ujedno i donja granica analitičkog određivanja (EC, 2005.). Definicija ostatka definirana je kao fipronil (zbroj fipronila + sulfon metabolita, MB46136) izraženih kao fipronil).

Danas se za određivanje fipronila $u$ hrani životinjskog podrijetla primjenjuju tehnike tekućinske i plinske kromatografije-tandemske spektrometrije masa, (LC-MS/MS, GC-MS/MS) nakon ekstrakcije uzoraka "Quick Easy Cheap Effective Rugged Safe" (QuECHERS) metodom (Zhang i sur., 2016., Hird i sur., 2017., Guo i sur., 2018.). QuECHERS metoda predstavljena je detaljno 2003. od Anastassiades i sur. Iako je prvotno QuEChERS uveden za analizu ostataka pesticida $u$ voću i povrću s visokim sadržajem vode, $\mathrm{u}$ novije vrijeme dobiva znatnu popularnost $\mathrm{u}$ analizi pesticida i ostalih spojeva $\mathrm{u}$ velikom broju prehrambenih proizvoda i ostalim različitim matricama (Lehotay, 2006.). 
Nizozemska agencija za sigurnost hrane i potrošačke proizvode (NVWA), čija je uloga zaštita zdravlja i dobrobiti ljudi i životinja u Nizozemskoj, dobila je 2016. godine anonimnu prijavu o nedopuštenoj uporabi fipronila $u$ proizvodima za čišćenje koji se koriste u farmama pilića. U srpnju 2017. stigla je obavijest iz Belgije putem EU RASFF portala (engl. Rapid Alert System for Food and Feed), odnosno centralnog sustava brzog uzbunjivanja za hranu i hranu za životinje, da je fipronil pronađen $u$ jajima u koncentraciji od 0,0031 do 1,2 $\mathrm{mg} / \mathrm{kg}$ (Hird i sur., 2017.). Otkriveno je da je fipronil nađen $\mathrm{u}$ sredstvu za čiščenje pod nazivom Dega-16 u koji je dodan da bi pojačao njegovo djelovanje te spriječio razmnožavanje crvenih grinja (Dermanyssus gallinae). Nadalje, pokrenuta je istraga te je za sada otkriveno da je fipronil kupljen kod kemijske tvrtke u Rumunjskoj te ilegalno stavljan u Dega-16. Sredstvo za čišćenje nije korišteno samo za suzbijanje štetočina $u$ Nizozemskoj, već i u njemačkoj saveznoj državi Donja Saska. Farme u kojima se fipronil koristio su zatvorene, a jaja povučena iz prodavaonica.

U zemljema članicama EU svako je jaje dobilo numerički kod tako da nadležno tijelo za sigurnost hrane, proizvođači hrane i potrošači podjednako mogu ući u trag zemlji podrijetla jaja pa čak i s koje farme jaje dolazi. Objavljeni su popisi kodova koji označavaju kontaminirana jaja i ta su jaja povučena s polica i uništena. Neki su supermarketi prestali prodavati jaja, a distribucija mnogih proizvođača jaja je obustavljena. Neki su ove mjere nazvali pretjeranim, ali taj je skandal teško pogodio nizozemske poljoprivrednike, s obzirom na to da se 60-70 \% nizozemskih jaja izvozi u zemlje poput Njemačke, koja je 2016. godine uvezla čak 5 milijardi jaja iz Nizozemske (Hird i sur., 2017.).

Kao posljedica ustvrđene zlouporabe fipronila na farmama pilića, države članice i Europska komisija dogovorile su na sastanku odbora PAFF (European Commission Standing Committee on Plants, Animals, Food and Feed) održanom 30. kolovoza 2017. u Bruxellesu organiziranje programa monitoringa. Europska komisija zatražila je od Europske agencije za sigurnost hrane (EFSA) tehničku pomoć u okviru članka 31. Uredbe (EZ) br. 178/2002 (EC, 2002.) za uspostavu ad-hoc prikupljanja podataka i sažimanje rezultata ad-hoc praćenja programa $u$ znanstvenom izvješću. EFSA je objavila izviješće u travnju 2018. godine. U ukupno 5439 uzoraka jaja i mesa peradi obuhvaćenih monitoringom $\mathrm{u}$ razdoblju između 1 . rujna i 30. studenog 2017. u zemljama članicama EU i Islandu u 742 (13,6 \%) uzoraka ustvrđene su količine veće od zakonski dopuštenih (EFSA, 2018.). Od 5439 analiziranih uzoraka čak 2 540 se odnosilo na sumnjive uzorke ili uzorke koji su bili usmjereni prema proizvodima/proizvođačima kod kojih se pretpostavljalo kršenje zakonskih prekoračenja. Preostalih 2899 uzoraka uzeto je nasumično, bez posebnog ciljanja prema proizvodima koji bi mogli biti nesukladni. Mala količina uzoraka odnosila se na proizvodnju prema principima organske poljoprivredne prakse (374 od 5439 uzoraka, 6,9\%).

Većina nesukladnih rezultata se odnosila na povišene koncentracije fipronila u uzorcima kokošjih jaja (601 uzorak), masnom tkivu kokoši nesilica (134 uzoraka), mišićnom tkivu kokoši nesilica (5 uzoraka) i dehidriranim jajima (2 uzorka). Uzorci koji su prekoračili zakonsko ograničenje bili su podrijetlom iz Nizozemske (664 uzoraka), Italije (40 uzoraka), Njemačke (13 uzoraka), Poljske (11 uzoraka), Mađarske (6 uzoraka), Francuske (5 uzoraka), Slovenije (2 uzorka) i Grčke (1 uzorak). Među 66 tvari koje su analizirane u okviru adhoc monitoringa, jedino su fipronil i amitraz bili kvantificirani. Uzorke 
s prekoračenjem najviše dopuštene količine (NDK) prijavilo je devet država članica, a podrijetlom su iz osam država članica: Nizozemske, Italije, Njemačke, Poljske, Mađarske, Francuske, Slovenije i Grčke. U ovome monitoringu sudjelovala je i Republika Hrvatska s ukupno 25 uzoraka te $u$ niti jednom uzorku nije bilo prekoračenja NDK od $0,005 \mathrm{mg} / \mathrm{kg}$ (EFSA, 2018.).

Izvan EU ispitivana je i pojava fipronila $\mathrm{u}$ proizvodima od peradi. $\mathrm{U}$ radu od Guo i sur. (2018.) metabolit fipronil-sulfon pronađen je $u$ većini od 214 uzoraka prikupljenih u Pekingu. U opsežnijoj studiji od Meiyu Zhang i sur. (2016.) koja je obuhvatila 120 uzoraka jaja i mišića sakupljenih iz različitih gradova $\mathrm{u}$ Kini fipronil je pronađen samo $\mathrm{u}$ jednom uzorku jaja.

\section{Rezultati kontrole fipronila s tržišta EU}

Zemlje članice EU nesukladne rezultate fipronila $\mathrm{u}$ kontroli proizvoda koji se upućuju na tržište EU prijavljuju kroz RASFF sustav (EC, 2002.). U razdoblju od prvog prijavljivanja od strane Belgijskog nadležnog tijela u periodu od 20. srpnja 2017. godine do prosinca 2019. godine prijavljeno je ukupno 128 različitih proizvoda s nesukladnim koncentracijama fipronila (RASFF 2017.-2019.). Od toga najviše obavijesti odnosilo se na jaja i proizvode od jaja (111), po 2 proizvoda pronađena su iz skupina meso peradi i proizvodi od mesa peradi, 2 iz skupina žitarica i pekarskih proizvoda, po jedan iz skupine hrane za životinje i ribe i ribljih proizvoda, dok je ostatak (njih 11) pripadalo skupini voća i povrća. U Tabeli 1 prikazan je broj ustvrđenih nesukladnih rezultata fipronila na razini EU.

Od 111 jaja i proizvoda od jaja najviše nesukladnih nalaza prijavila je Italija (68), dok su ostale zemlje s brojem prijavljenih nesukladnih nalaza redom bile: Malta (7), Poljska i Slovačka (svaka po 6), Nizozemska (4). Po 3 nesukladna jaja i proizvoda od jaja prijavile su Belgija, Češka, Njemačka i Mađarska, po 2 Bugarska i Grčka dok su po jedan nesukladan nalaz prijavile Austrija, Francuska, Luksemburg i Norveška. Većina jaja (109) prijavljena je tijekom 2017. godine, dok su samo dvije prijave bile tijekom 2018. godine, a niti jedna tijekom 2019.

Tabela 1. Broj ustvrđenih nesukladnih rezultata fipronila na razini EU u razdoblju od 20.srpnja 2017. do kraja 2019. (RASFF 2017.-2019).

\begin{tabular}{|l|c|l|}
\hline Vrsta proizvoda & $\begin{array}{l}\text { Broj neukladnih } \\
\text { rezultata }\end{array}$ & $\begin{array}{l}\text { Članica EU koja je prijavila nesukladan } \\
\text { rezultat }\end{array}$ \\
\hline $\begin{array}{l}\text { Meso peradi i proizvodi od } \\
\text { mesa peradi }\end{array}$ & 2 & \begin{tabular}{l} 
Mađarska, Nizozemska \\
\hline Voće i povrće
\end{tabular} \\
\hline Riba i riblji proizvodi & 11 & $\begin{array}{l}\text { Austrija, Češka, Francuska, Njemačka, } \\
\text { Nizozemska, Španjolska }\end{array}$ \\
\hline Hrana za životinje & 1 & Austrija \\
\hline Žitarice i pekarski proizvodi & 1 & Njemačka \\
\hline Jaja i proizvodi od jaja & 2 & Italija \\
\hline & 111 & $\begin{array}{l}\text { Austrija, Belgija, Bugarska, Češka, } \\
\text { Francuska, Njemačka, Grčka, Mađarska, } \\
\text { Italija, Luksemburg, Malta, Nizozemska, } \\
\text { Norveška, Poljska, Slovačka }\end{array}$ \\
\hline
\end{tabular}


Od dva prijavljena proizvoda iz skupine mesa peradi i proizvoda od mesa peradi jedan je prijavila Mađarska, a ticao se smrznutih očišćenih malih pilića podrijetlom iz Rumunjske u kojima je pronađeno 0,067 mg/kg fipronila. Drugi proizvod, dehidrirano meso piletine, podrijetlom sirovine iz Španjolske i Ujedinjenog Kraljevstva prijavila je Nizozemska te je $\mathrm{u}$ njemu ustvrđeno 0,0252 i 0,0223 mg/kg fipronila.

Oba nesukladna nalaza iz skupine žitarica i pekarskih proizvoda prijavila je Italija pa su tako u tjestenini podrijetlom iz Italije ustvrdili $0,127 \mathrm{mg} / \mathrm{kg}$ fipronila dok su u pasteriziranoj mješavini jaja za kolače (podrijetlom iz Italije) odredili 0,012 $\mathrm{mg} / \mathrm{kg}$ fipronila.
Najveća zabilježena koncentracija fipronila ustvrđena je $\mathrm{u}$ jajima $\mathrm{u}$ prahu podrijetlom iz Rumunjske, Poljske i Češke te je iznosila $1,9 \mathrm{mg} / \mathrm{kg}$ fipronila. Od 111 prijavljenih jaja i proizvoda od jaja samo su 4 pripadala kategoriji ozbiljnog rizika (serious risk). U njih je ustvrđena koncentracija fipronila $u$ jajima čak i do $1,4 \mathrm{mg} / \mathrm{kg}$ što je prikazano u Tabeli 2.

Kada govorimo o poduzetim mjerama u čak 45 prijava na RASFF sustav kontaminirana jaja povučena su s tržišta, obavljeno je po 9 zapljena i 9 službenih pritvora te je u 8 slučajeva obaviješteno nadležno tijelo. Ostale poduzete mjere prikazane su na Slici 1.

Tabela 2. Uzorci jaja s nesukladnim koncentracijama fipronila koji spadaju u kategoriju ozbiljnog rizika (RASFF 2017.-2019).

\begin{tabular}{|l|l|l|l|l|}
\hline Datum prijave & $\begin{array}{l}\text { Članica } \\
\text { prijave }\end{array}$ & $\begin{array}{l}\text { Vrsta } \\
\text { proizvoda }\end{array}$ & $\begin{array}{l}\text { Koncentracija } \\
\text { fipronila }(\mathbf{m g} / \mathbf{k g})\end{array}$ & $\begin{array}{l}\text { Zemlja podrijetla } \\
\text { proizvoda }\end{array}$ \\
\hline 20.7.2017. & Belgija & jaja & $0,0031-1,2$ & nepoznata \\
\hline 28.8.2017. & Italija & jaja & 1,2 & Rumunjska \\
\hline 4.9 .2017$. & Italija & jaja & 1,$21 ; 1,22$ & Italija \\
\hline 22.9 .2017$. & Italija & jaja & 1,$4 ; 0,78 ; 0,65$ & Italija \\
\hline
\end{tabular}

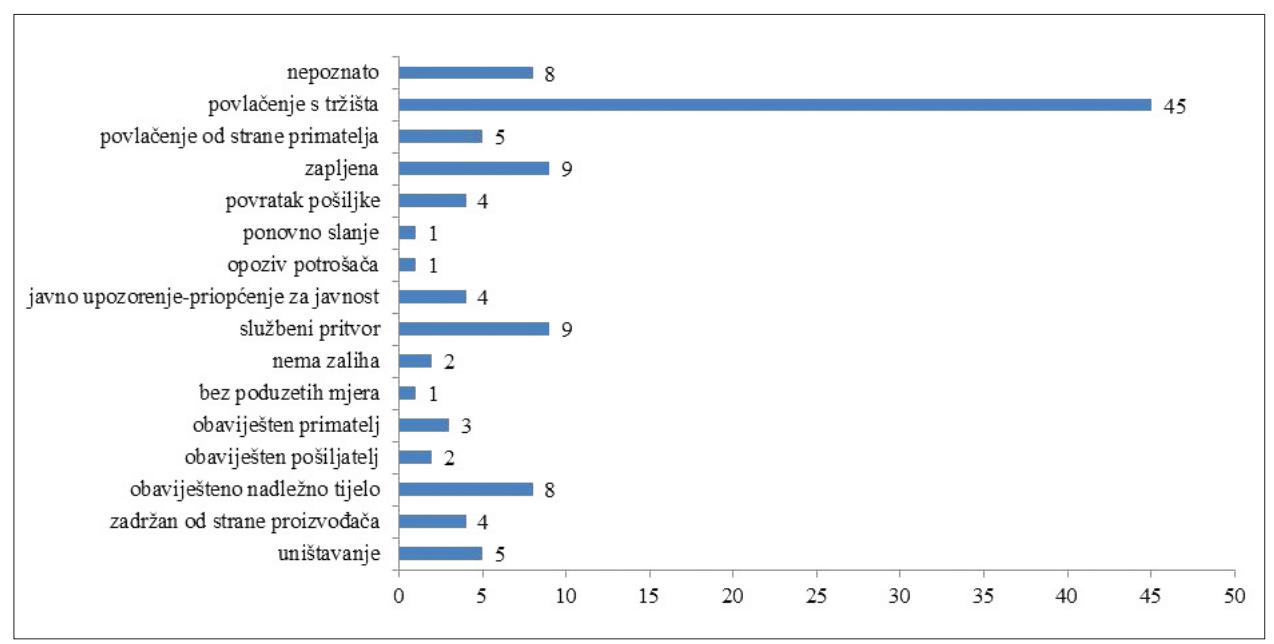

Slika 2. RASFF poduzete mjere u razdoblju od 20. srpnja 2017. do kraja 2019. (RASFF 2017.-2019). 
S obzirom na ustvrđene nesukladne nalaze fipronila Europska komisija je uvrstila fipronil kao obveznu tvar koja se mora kontrolirati u okviru koordiniranog višegodišnjeg programa kontrole EU koji se planira za osiguranje sukladnosti s maksimalnim razinama ostataka pesticida i ocjenu izloženosti potrošača ostatcima pesticida u i na hrani biljnog i životinjskog podrijetla za razdoblje 2020.-2022. (EC, 2019.). Pri tome je u hrani životinjskog podrijetla planirana kontrola fipronila u hrani životinjskog podrijetla za razdoblje te tri godine za goveđu jetru, jaja i svinjsku mast.

Njemački Savezni institut za procjenu rizika je na temelju količina fipronila ustvrđenih u kokošjim jajima i mesu napravio procjenu štetnog utjecaja na zdravlje ljudi (BfR, 2017.). Procjena je izrađena je na osnovi prekoračenja akutne referentne doze (ARfD) od 0,009 $\mathrm{mg} / \mathrm{kg}$ tjelesne mase, koja je dobivena $\mathrm{u}$ okviru EU procjene aktivne tvari sadržane $u$ sredstvima za zaštitu bilja. Prema prehrambenim navikama Nijemaca u konzumiranju kokošjih jaja ili pilećeg mesa zagađenog fipronilom ArfD vrijednost nije prekoračena niti kod jedne od ispitanih potrošačkih skupina. Kada se uzmu u obzir podatci o europskoj potrošnji za djecu (dojenčad u Velikoj Britaniji), ARfD je premašen u slučaju djece za kokošja jaja kada iznosi 1,6. To ne mora nužno značiti da postoji konkretan zdravstveni rizik konzumiranjem pilećih jaja, ali ukazuje da je, kad su djeca u pitanju, moguća opasnost za zdravlje $s$ potrebnom razinom sigurnosti nakon konzumiranja kontaminiranih pilećih jaja. Na temelju dva dostupna modela izloženosti, koncentracija fipronila od $0,72 \mathrm{mg} / \mathrm{kg}$ (zbroj fipronila i metabolita sulfona izračunata kao fipronil) može se smatrati najvišom koncentracijom $u$ pilećim jajima u kojih ne postoji akutni rizik za zdravlje ispitivanih potrošačkih skupina, jer u ovom slučaju ARfD nije premašen (BfR, 2017.).

\section{Literatura}

1. ANASTASSIADES, M., S. J. LEHOTAY, D. STAJNBAHER and F. J. SCHENCK (2003): Fast and easy multiresidue method employing acetonitrile extraction/partitioning and "dispersive solid-phase extraction" for the determination of pesticide residues in produce. J. AOAC Int. 86, 412-431.

2. BAUMAN, S. W., R. BAUR and E. SIGEL (2002): Forced subunit assembly in alpha1beta2gamma2 GABAA receptors. Insight into the absolute arrangement. J. Biol. Chem. 277, 46020-46025.

3. BfR (2017): Health assessment of individual measurements of Fipronil levels detected in foods of animal origin in Belgium. The German Federal Institute for Risk Assessment, BfR Opinion No. 016/2017 of 30 July 2017.

4. DURHAM, E. W., B. D. SIEGFRIED and M. E. SCHARF (2002): In vivo and in vitro metabolism of fipronil by larvae of the European corn borer Ostrinia nubilalis. Pest. Manag. Sci. 58, 799-804.

5. GUO, Q., S. ZHAO, J. ZHANG, K. QI, Z. DU and B. SHAO (2018): Determination of fipronil and its metabolites in chicken egg, muscle and cake by a modified QuEChERS method coupled with LC-MS/ MS. Food. Addit. Contam. 35, 1543-1552.

6. HAINZL, D. and J. E. CASIDA (1996): Fipronil insecticide: novel photochemical desulfinylation with retention of neurotoxicity." Proceedings of the National Academy of Sciences of the United States of America. 93, no. 23, pp. 12764-12767.

7. HAINZL, D., L. M. COLE and J. E. CASIDA (1998): Mechanisms for selective toxicity of fipronil insecticide and its sulfone metabolite and desulfinyl photoproduct. Chem. Res. Toxicol. 11, 1529-1535.

8. HIRD, S., E. ROSS, C. DECLERCQ, W. DEMEYER, H. BRAECKMAN, J. CLAEREBOUDT and M. VAN HULLE (2017): Fipronil and Fipronil Sulfone in Eggs: Background and Method of Analysis. 10 August, 2017. Dostupno na: https:// www.linkedin.com/pulse/fipronil-sulfone-eggsbackground-method-analysis-euan-ross?trk=v feed\&lipi=urn\%3Ali\%3Apage\%3Ad_flagship3_ detail_base\%3B4\%2BQzsTqtct\%2Fu1ySwk7fyjQ\%3 D\%3D. Pristupljeno 7.1.2020.

9. EC (2002): Regulation (EC) No 178/2002 of the European Parliament and of the Council of 28 January 2002 laying down the general principles and requirements of food law, establishing the European Food Safety Authority and laying down procedures in matters of food safety. Off. J. Eur. Commun. L31, 1-24

10. EC (2005): Regulation (Ec) No 396/2005 of the European parliament and of the council of 23 February 2005 on maximum residue levels of pesticides in or on food and feed of plant and animal origin andamending Council Directive 91/414/EEC. Off. J. Eur. Union. L70. 1-3308.

11. EC (2009): Regulation (EC) No $1107 / 2009$ of the European parliament and of the council of 21 October 2009 concerning the placing of plant 
protection products on the market and repealing Council Directives 79/117/EEC and 91/414/EEC. Off. J. Eur. Commun. L309, 1-50.

12. EC (2019): Commission Implementing Regulation (EU) 2019/533 of 28 March 2019 concerning a coordinated multiannual control programme of the Union for 2020, 2021 and 2022 to ensure compliance with maximum residue levels of pesticides and to assess the consumer exposure to pesticide residues in and on food of plant and animal origin. Off. J. Eur. Commun. L88, 22-41.

13. EFSA (2006): Conclusion regarding the peer review of the pesticide risk assessment of the active substance - fipronil. EFSA Scientific Report 65, 1-110.

14. EFSA (2018): Scientific report on the occurrence of residues of fipronil and other acaricides in chicken eggs and poultry muscle/fat. EFSA Journal 16, 5164.

15. GUO, Q., S. ZHAO, J. ZHANG, K. QI, Z. DU and B. SHAO (2018): Determination of fipronil and its metabolites in chicken egg, muscle and cake by a modified QuEChERS method coupled with LC-MS/ MS. Food Addit. Contam. A 35, 1543-1552.

16. IKEDA, T., K. NAGATA, Y. KONO, J. Z. YEH and T. NARAHASHI (2004): Fipronil modulation of GABAA receptor single- channel currents. Pest. Manag. Sci. 60, 487-492.

17. IPCS/INCHEM (1997): International Programme on Chemical Safety. Fipronil. Pesticide Residues in Food - 1997. Dostupno na: http://www.inchem. org/documents/jmpr/jmpmono/v097pr09.htm. Pristupljeno 12.11.2019.

18. ISLAM, R. and J. W. LYNCH (2012): Mechanism of action of the insecticides, lindane and fipronil, on glycine receptor chloride channels. Br. J. Pharmacol. $165,2707-2720$.

19. LEHOTAY, S. J. (2006): Quick, Easy, Cheap, Effective, Rugged and Safe (QuEChERS) approach for determining pesticide residues. In: Vidal Martinez J. L., Garrido Frenich A., Pesticide protocols, Humana Press, USA (239-261).

20. MAGALHÃES, J., T. SANDINI, M. BERTO UDO, A. FUKUSHIMA and H. SPINOSA (2018): Fipronil: uses, pharmacological and toxicological features. Revinter: Revista Intertox de Toxicologia, Risco Ambiental e Sociedade ISSN: $1984-3577$ v. 11, n. 01, p. 67-83.

21. MEIYU ZHANG, K. B., T. ZHOU, X. SONG, Q. LIU, C. MENG and L. HE (2016): Determination of residual fipronil in chicken egg and muscle by LCMS/MS. J. Chromatogr. B 1014, 31-36.

22. Ministarstvo poljoprivrede (2020): Popis veterinarsko-medicinskih proizvoda (VMP), stanje na dan 17. veljače 2020. godine. Dostupno na: http://www.veterinarstvo.hr/default.aspx?id=140. Pristupljeno 25.02.2020.

23. MOHAMED, F, L. SENARATHNA, A. PERCY, M. ABEYEWARDENE, G. EAGLESHAM, R. CHENG, S. AZHER, A. HITTARAGE, W. DISSANAYAKE, M. H. SHERIFF, W. DAVIES, N. A. BUCKLEY and M. EDDLESTON (2004): Acute human self- poisoning with the N-phenylpyrazole insecticide fipronil--aGABAA-gated chloride channel blocker. J. Toxicol. Clin. Toxicol. 42, 955-963.

24. NARAHASHI, T., X. ZHAO, T. IKEDA, K. NAGATA and J. Z. YEH (2007): Differential actions of insecticides on target sites: basis for selective toxicity. Hum. Exp. Toxicol. 26, 361-366.

25. NCAMP (2016): National coalition against the misuse of pesticides. Chemical watch gactsheet: Fipronil. Dostupno na: http://npic.orst.edu/ factsheets/fipronil.html. Pristupljeno 12.11.2019.

26. NCAP (2005): Northwest coalition for alternatives to pesticide. Fipronil. J. Pest. Ref. 25, 10-15.

27. NPIC (2009): National Pesticide Information Center. Fipronil. Oregon State University and the U.S. Environmental Protection Agency. Dostupno na: http://npic.orst.edu/factsheets/fipronil.pdf. Pristupljeno 12.11.2019.

28. OHI, M., P. R. DALSENTER, A. J. ANDRADE and A. J. NASCIMENTO (2004): Reproductive adverse effects of fipronil in Wistar rats. Toxicol. Lett.146, 121-127.

29. OLSEN, R. W. and W. SIEGHART (2008): Subtypes of $\gamma$-aminobutyric acid (A) receptors: classification on the basis of subunit composition, pharmacology and function. Pharmacol. Rev. 60, 243-260.

30. RASFF (2017.-2019): Rapid alert system for food and feed(RASFF).Dostupnona:https://webgate.ec.europa. eu/rasff-window/portal/?event=searchResultList. Pristupljeno 10.01.2020.

31. SZEGEDI, V., G. BÁRDOS, L. DÉTÁRI, A. TÓTH, I. BANCZEROWSKI-PELYHE and I. VILÁGI (2005): Transient alterations in neuronal and behavioral activity following bensultap and fipronil treatment in rats. Toxicology 214, 67-76.

32. TERÇARIOL, P. R. G. (2007): Avaliação neurocomportamental de ratos expostos agudamente ao fipronil - Influência de Diazepam e Flumazenil. 78f. Tese (Mestrado em Ciência Veterinária) - Faculdade de Medicina Veterinária e Zootecnia, Universidade Estadual Paulista Julio de Mesquita Filho, UNESP, Botucatu.

33. TINGLE, C. C. D., J. A., ROTHER, C. F. DEWHURST, S. LAUER and W. J. KING (2003): Fipronil: environmental fate, ecotoxicology and human health concerns. Rev. Environ. Contam. T. 176, 1-66.

34. WHO (2010): The WHO recommended classification of pesticides by hazard and guidelines to classification 2009. Dostupno na: https://apps.who. int/iris/handle/10665/44271. Pristupljeno 5.11.2019.

35. ZHANG, M., K. BIAN, T. ZHOU, X. SONG, Q. LIU, C. MENG and L. HE (2016): Determination of residual fipronil in chicken egg and muscle by LCMS/MS. J. Chromatogr. B 1014, 31-36.

36. ZHAO, X., J. Z YEH, V. L., SALGADO and T. NARAHASHI (2005): Sulfone metabolite of fipronil blocks gamma-aminobutyric acidand glutamate-activated chloride channels in mammalian and insect neurons. J. Pharmacol. Exp. Ther. 314, 363-373. 


\section{Insecticide fipronil in poultry products in the European Union}

Maja ĐOKIĆ, PhD, Grad. Chem. Technol. Eng., Marija SEDAK, PhD, Grad. Food Technol. Eng., Nina BILANDŽIĆ, PhD, Grad. Biotechnol. Eng., Scientific Advisor, Croatian Veterinary Institute, Zagreb, Croatia

Fipronil is a broad-spectrum insecticide that belongs to the phenylpyrazole group. It is an insecticide that acts by targeting the GABA (gamma aminobutyric acid) receptor and has favourable selective toxicity to insects rather than mammals. Pursuant to Regulation (EC) No. 1107/2009, fipronil is not authorized in plant protection products and it is forbidden to treat animals intended for human consumption in the European Union (EU). The maximum permitted residue level (MRL) of fipronil is $0.005 \mathrm{mg} /$ $\mathrm{kg}$ for eggs and poultry, as established under Regulation 396/2005 on maximum levels of pesticide residues in and on food and feed of plant and animal origin. The World Health Organization (WHO) has classified fipronil as a mildly dangerous class II pesticide. Consuming small amounts of fipronil causes nausea, headache, vomiting, stomach pain, weakness and dizziness. After absorption in humans, it is distributed into tissues and releases active metabolites that accumulate mainly in adipose tissue. Experiments in mice have shown that prolonged exposure to high doses of fipronil causes thyroid cancer in males and females. The occurrence of fipronil in eggs in the EU was reported in Belgium in 2016. As a consequence of the identified misuse of fipronil found on chicken farms, EU Member States and the European Commission have agreed to carry out ad-hoc monitoring of fipronil insecticides and other acaricides in eggs and poultry meat. In a monitoring report published by the European Food Safety Authority (EFSA), 742 samples $(13.6 \%)$ of a total of 5439 eggs and poultry samples in EU Member States and Iceland exceeded the legal limits. Most inconsistent results were related to fipronil in chicken eggs and fat of laying hens. No non-compliant results were found in samples from the Republic of Croatia. Samples exceeding the legal limit originated from the Netherlands, Italy, Germany, Poland, Hungary, France, Slovenia and Greece. EU Member States reported non-compliant fipronil results in the control of products marketed in the EU during 2017-2019 via the Central Rapid Alert System for Food and Feed (RASFF). In total, 128 different products with non-compliant fipronil concentrations were reported, with the most reports regarding eggs and egg products. In the framework of the measures taken, as many as 45 complaints were filed to withdraw contaminated eggs from the market, and nine confiscations and nine official detentions were carried out. Based on the identified non-compliant findings of fipronil, the European Commission has listed its control under Commission Coordinated Implementing Regulation (EU) 2019/533 under the coordinated multi-annual EU control program for the period 2020-2022.

Key words: fipronil; pesticides; eggs; EFSA; food safety 